\title{
Dependency of Specific Energy of Rock Cutting on Specific Drilling Energy
}

The Mining-Geology-Petroleum Engineering Bulletin UDC: 621.9:552.1

DOI: $10.17794 /$ rgn.2018.3.3

Preliminary communication

\author{
Davor Antoljak'; Dalibor Kuhinek²; Tomislav Korman³; Trpimir Kujundžićc \\ ${ }^{1}$ Zagorska 6, 43000 Bjelovar \\ ${ }^{2}$ University of Zagreb, Faculty of Mining, Geology and Petroleum Engineering, Pierottijeva 6, 10000 Zagreb \\ ${ }^{3}$ University of Zagreb, Faculty of Mining, Geology and Petroleum Engineering, Pierottijeva 6, 10000 Zagreb \\ ${ }^{4}$ University of Zagreb, Faculty of Mining, Geology and Petroleum Engineering, Pierottijeva 6, 10000 Zagreb
}

\begin{abstract}
Specific energy is the measure which connects the operating parameters of a machine with the characteristics of the rock in which the machine works and is equal to the total work required to break a unit volume of the rock. It is assumed that in machines with the same or similar rock breaking mechanics used for different purposes (e.g. cutting and drilling of rocks), there is a significant dependence on their specific energy values. In the exploitation of dimension stone a chain saw and a rotary drill are often used, i.e. the machines for rock cutting or rock drilling whereas their mechanics of rock breaking are very similar. In order to determine the dependence of the specific energy of rock cutting on the specific drilling energy, preliminary laboratory tests were carried out on a linear cutting machine and a laboratory drilling rig with simulated cutting of rocks with a chain saw, and drilling by rotary drilling rig. The analysis of the measurement results has provided the guidelines for the continuation of laboratory testing, i.e. field testing.
\end{abstract}

Keywords:

Rock breaking, drilling, cutting, specific energy.

\section{Introduction}

Drilling and cutting are processes for rock breaking that are commonly used during the exploration and exploitation of mineral raw materials, i.e. during geotechnical and other works. There are many types of drilling and cutting machines, depending on their purpose and type of rock breaking. In processes where the mechanics (statics, kinematics, dynamics) of rock breaking by drilling and cutting is the same or similar, it is possible to determine the dependence between certain operating values of drilling machines and rock cutting machines.

Specific energy is the measure which connects the operating parameters of the machine and the properties of the rock or rock mass into one unit. The specific energy of drilling or cutting is the total energy (work) required to break a unit volume of the rock (Teale, 1965). Generally, specific energy can be calculated using the Equation (1):

$$
S E=\frac{\sum W}{V}
$$

where:

$$
\begin{aligned}
& S E \text { - specific energy }\left(\mathrm{J} / \mathrm{m}^{3}\right), \\
& W \text { - work required to break a unit volume of rock }(\mathrm{J}), \\
& V \text { - unit volume of } \operatorname{rock}\left(\mathrm{m}^{3}\right) .
\end{aligned}
$$

Corresponding author: Davor Antoljak

e-mail:davor.antoljak@gmail.com
For the efficient obtaining of primary blocks of dimension stone, a combination of diamond wire saw and chain saw is often used. Horizontal and/or vertical boreholes are drilled by a hydraulic rotary drilling rig to allow diamond wire pulling. The rock breaking mechanism of the chain saw and the hydraulic rotary drilling machine is very similar. For the purpose of confirming the dependence of the specific energy of rock cutting on the specific drilling energy, laboratory measurements of specific energies have been carried out.

The specific energy of drilling, i.e. cutting, was measured on a laboratory rotary drilling rig, i.e., on the linear cutting machine (modified metalworking shaper). In the next step of exploring the specific energy dependencies, additional laboratory measurements and field measurements are planned on the exploitation field of dimension stone on the hydraulic rotary drilling rig and on chain saw.

A very good correspondence of the specific cutting energy tested in the laboratory on a linear cutting machine with the field tests (chain saw) was proved and presented in the PhD thesis by Korman (2014). In other words, the linear cutting machine can be used to simulate the cutting process of the chain saw (Korman at al., 2015b). The same analogy will be used to explore the possibility of simulating on-site (field) rotation drilling on a laboratory drilling rig. 


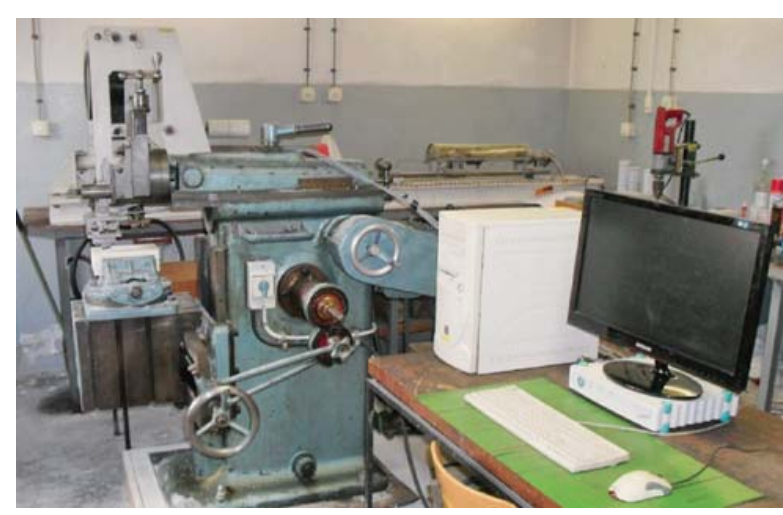

Figure 1: Linear cutting machine with measuring system with force transducer (Korman, 2014)

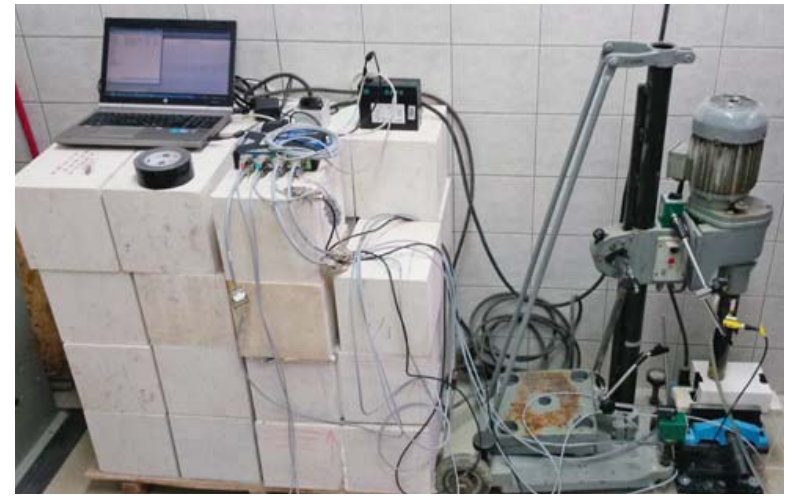

Figure 2: Laboratory drilling rig with measuring system for drilling energy measurement

Table 1: Characteristics of the electric motor drive for linear cutting machine and laboratory drilling rig

\begin{tabular}{|l|c|c|c|c|c|}
\hline \multirow{2}{*}{ Physical quantity } & \multirow{2}{*}{ Symbol } & $\begin{array}{c}\text { Linear cutting } \\
\text { machine }\end{array}$ & $\begin{array}{c}\text { Laboratory } \\
\text { drilling rig }\end{array}$ & \multirow{2}{*}{$\begin{array}{c}\text { Unit of } \\
\text { measurement }\end{array}$} & \multirow{2}{*}{ Note } \\
\cline { 3 - 6 } & & \multicolumn{2}{|c|}{ Value } & $(\mathrm{W})$ & \\
\hline Electrical power & $P$ & 2200 & 3000 & $(\mathrm{~V})$ & triangle/star \\
\hline Electrical voltage & $U$ & $220 / 380$ & $220 / 380$ & $(\mathrm{~A})$ & triangle/star \\
\hline Electrical current & $I$ & $8.7 / 5$ & $8 / 4.6$ & & \\
\hline Power factor & $\cos \varphi$ & 0.83 & 0.91 & $(\mathrm{~Hz})$ & \\
\hline Frequency & $f$ & 50 & 50 & $(\mathrm{rpm})$ & \\
\hline Number of revolutions & $N$ & 1415 & 2835 & & \\
\hline
\end{tabular}

Table 2: Geometric size of the cutting tool

\begin{tabular}{|l|c|c|c|}
\hline \multirow{2}{*}{ Cutting Tool } & Rake Angle & Side Angle & Side Rake Angle \\
\cline { 2 - 4 } & $\left({ }^{\circ}\right)$ & $\left({ }^{\circ}\right)$ & $\left({ }^{\circ}\right)$ \\
\hline S1 & 7.3 & 45 & 0 \\
\hline
\end{tabular}

\section{Laboratory measurements}

Laboratory measurements were carried out in the Laboratory for geomechanics and the Laboratory for mining machinery and dimension stone at the Faculty of Mining, Geology and Petroleum Engineering of the University of Zagreb. The values needed to calculate the specific cutting, i.e. drilling energy were measured on a linear cutting machine and on a drilling rig for coring with a diamond drill bit, using two measurement systems, the system for measuring energy used for cutting or drilling and the system for measuring using a force transducer.

The rock sample is a recrystallized limestone of organic origin collected on the exploitation field of dimension stone Redi near Trogir. The delivered sample was cut into the dimensions adapted to the dimensions of the vice for the linear cutting machine and the laboratory drilling rig.

\subsection{Linear cutting machine and laboratory drilling rig}

The linear cutting machine is the modified mechanical metalworking shaper machine (see Figure 1). Cut- ting on a shaper is a metalworking process in which the particles from the workpiece are separated through the linear movement of the cutting tool or the blade of a certain geometry. The technical data of the electric motor drive of the linear cutting machine is shown in Table $\mathbf{1 .}$ The modification of the linear cutting machine consisted of the replacement of a metalworking tool with a tungsten-carbide tool (stone chain saw cutting element) and the installation of a three-axis force transducer on the tool holder (Korman, 2014). The geometrical features of the cutting tool are presented in Table 2.

The laboratory coring drill with diamond bit (see Figure 2) is used to prepare cores from rock samples used to test the physical and mechanical properties of rocks (e.g. uniaxial compressive strength). The drilling mechanisam of the laboratory drilling rig is rotary drilling. The technical data of the electric motor drive of the laboratory drilling rig is shown in Table $\mathbf{1}$.

\subsection{Measuring system for measuring energy of cutting or drilling}

Due to the fact of that no standard has been established which would specify the method or methods for testing the specific energy of cutting i.e. rock drilling, a method for laboratory testing specific energy has been developed. The method consists of several measurement procedures during which different measuring instruments, i.e. measuring systems, are used. 
The energy used up upon cutting, i.e. drilling depends on the operating parameters of the linear cutting machine or the laboratory drilling rig and the properties of rocks that are cut or drilled. The cutting or drilling energy can be measured indirectly by measuring the electric power of the three-phase electric motor drive. When it comes to alternating current, the electric power changes in time, and the power at any moment is equal to the product of the voltage and electric current.

The change of electrical power in the time causes that the electrical energy (work) is also changed. The electric energy equals the area below the curve of power over time and can be calculated by Equation (2):

where:

$$
E=\int_{t_{o}}^{t_{k}} P(t) \cdot d t
$$

$E$ - energy (J),

$P$ - active power (W),

$t_{0}$ - start-up time (s),

$t_{k}$ - end time (s).

To measure the electrical power i.e. the energy, the measuring transducer Iskra MT540 was used. With the MT540 transducer it is possible to measure a large number of different electrical values and to monitor the operation of single-phase or three-phase power grids. The measured quantities of the effective electrical voltage and current are, by means of the embedded microcontroller, converted into other electrical quantities (e.g. power, energy, power factor, etc.).

The measured total active power is converted by MT540 to a DC voltage signal proportional to the total active power of the load. The transducer constant is $10 \mathrm{~V}$
$=6000 \mathrm{~W}$. The measuring transducer is connected to the NI MyDAQ data acquisition device which is connected to the computer via a USB cable. The data acquisition device can measure voltages within a range of $\pm 2 \mathrm{~V}$ to \pm $10 \mathrm{~V}$ in 16-bit resolution on 2 differential channels (Korman, 2014). The data acquisition device collects samples at a rate of $10000 \mathrm{~S} / \mathrm{s}$ in blocks of 500 samples that are averaged. The averaging is performed to reduce the noise. Accordingly, the sampling rate is $20 \mathrm{~Hz}$. The data aquisition device is managed using LabVIEW software. LabVIEW is a graphically-programmable design platform for data acquisition measurement control, signal analysis and processing, automation and process control, etc. During measurement, the LabVIEW results of measurements can be monitored on the voltage-time, total active power-time and energy-time diagrams. At the same time, the measured data is recorded on the hard disk of the computer. The data processing block diagram is shown in Figure 3.

A very similar measurement system was used by Korman when studying the influence of construction and operating parameters on the efficacy of the chain saw (Korman, 2014) and the influence of the physical and mechanical characteristics of rocks on energy consumption of the jaw crusher during crushing (Korman et al., 2015a).

Measurement starts by horizontal levelling and firming the rock sample and starting the electric motor of the machine used for linear cutting of the rocks or the use of the laboratory drilling rig. Data recording starts immediately after start-up to determine the idle energy. Once the measured idle values are recorded, the cutting, i.e. the drilling of the rock samples begins and the data continue to be recorded. The specific cutting i.e. drilling energy is

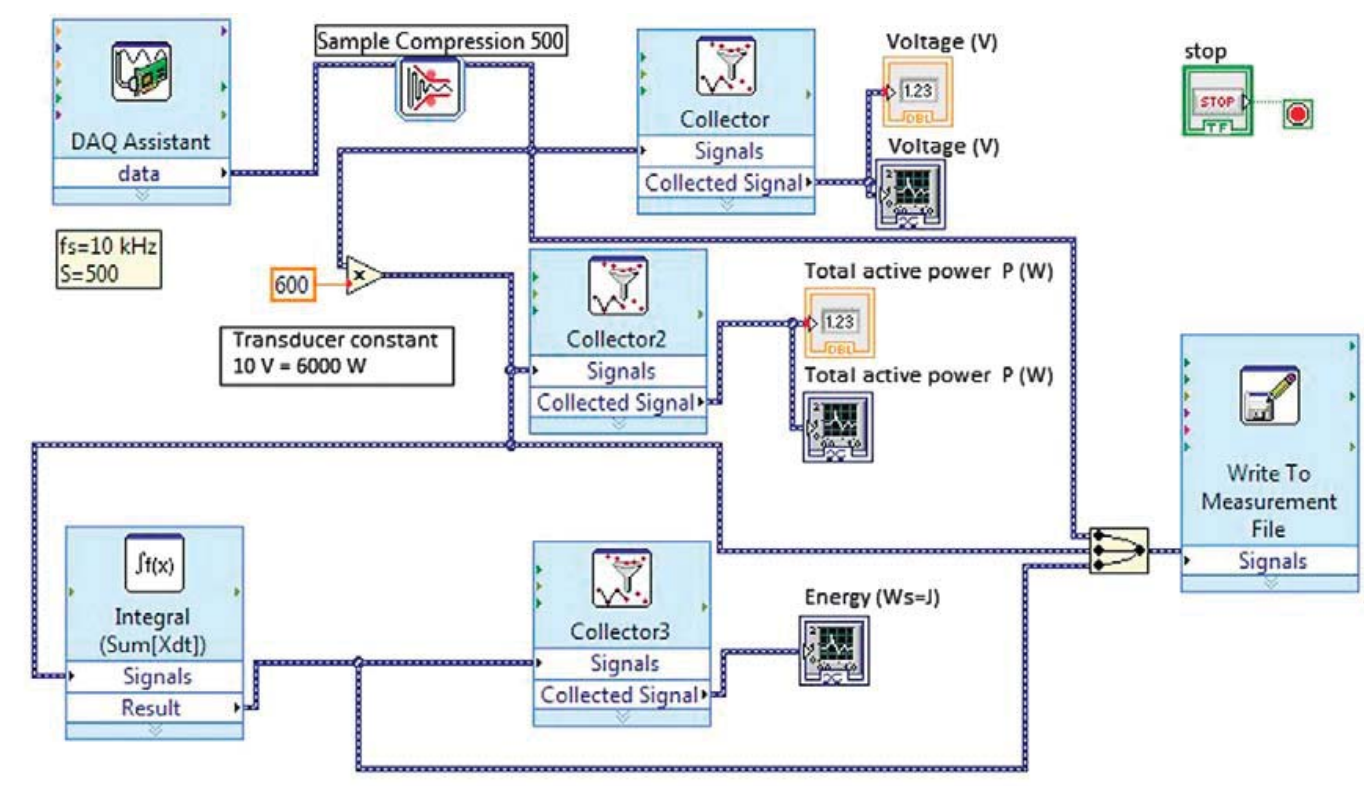

Figure 3: Block diagram of data processing 
the energy (work) used for cutting i.e. drilling of the unit volume of the rock. They are calculated using Equations (3) and (4).

$$
\begin{aligned}
& S E_{R}=\frac{E_{R}}{V_{r}} \\
& S E_{B}=\frac{E_{B}}{V_{r}}
\end{aligned}
$$

where:

$S E_{R}$ - specific cutting energy $\left(\mathrm{J} / \mathrm{m}^{3}\right)$,

$S E_{B}$ - specific drilling energy $\left(\mathrm{J} / \mathrm{m}^{3}\right)$,

$E_{R}$ - rock cutting energy $(\mathrm{J})$,

$E_{B}$ - rock drilling energy $(\mathrm{J})$,

$V_{r}$ - volume of rock chips $\left(\mathrm{m}^{3}\right)$.

Using the programmed routine in the LabVIEW application the total drilling energy was calculated by integrating the active power in the specific time interval. Using the measured data and energy-time diagrams, the characteristic values required to calculate cutting, i.e. drilling energy are determined. Using the Equations (5), (6), (7), (8) and (9) the above-mentioned values are calculated.

$$
\begin{gathered}
E_{R}=E_{B}=\Delta E-E_{P H} \\
\Delta E=E_{K}-E_{P} \\
E_{P H}=P_{P H s r} \cdot t_{r}=P_{P H s r} \cdot t_{b} \\
t_{r}=t_{r 2}-t_{r 1} \\
t_{b}=t_{b 2}-t_{b 1}
\end{gathered}
$$

where:

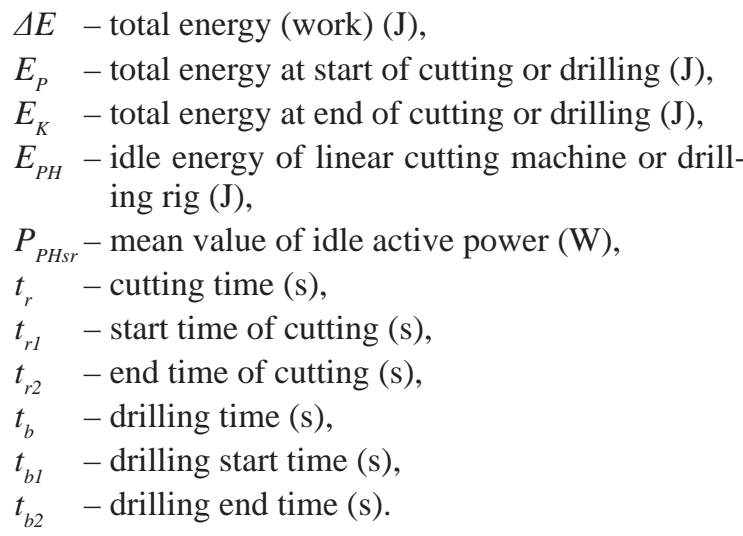

\subsection{Measuring system with force transducer}

Upon rock cutting or rock drilling, forces appear on the cutting tool and the rock contact that need to be measured in order to understand, control and manage the process of cutting, i.e. drilling. A force acting on a particular body results in displacement and/or deformation that can be measured. Therefore, the forces on the cutting tool are mostly measured by indirect methods: by measuring deformation or displacement.
Although there are a wide range of analytical models in literature (Wojtanowicz and Kuru, 1993; Chiaia at al., 2013; Mellor, 1976a; 1976b; 1978 and 1981) explaining rock breaking mechanics, none of them provide any accurate or precise method of calculating the resulting force of cutting or drilling as it is possible in the experimental testing of force. The reason for the deviation of the value of force obtained by analytical methods compared to the force values obtained by experimental tests is the complex mechanics of rock destruction and a large number of dependent physical quantities affecting the process of cutting i.e. rock drilling.

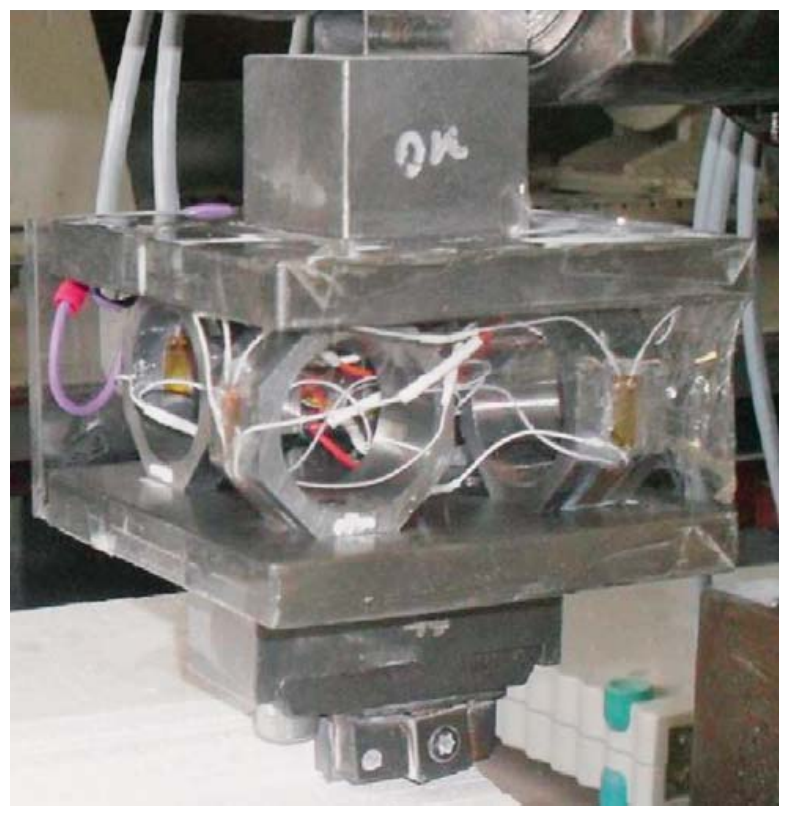

Figure 4: Three-axis force transducer with strain gauges

(Korman, 2014)

The three-axis force transducer measuring system was used to measure forces acting on the cutting tool due to the cutting of the rock sample (see Figure 4). A detailed description of transducer design and of the measuring system is given in another work (Korman, 2014). The measurement begins with horizontal levelling and firming of the rock sample and by engaging the electrical motor of the liner cutting machine. Data recording starts immediately after it is started and continues until the end of the cutting process. Using the measured data, the specific cutting energy was calculated.

A three-axis force transducer is connected to the HBM Spider 8 data acquisition device, which is also a power source for Wheatstone measurement bridges. In addition, the HBM Spider 8 can be used to amplify and filter the measured signals. The sampling rate was $4800 \mathrm{~Hz}$. HBM Spider 8 is connected to a computer via a parallel interface. It is managed and controlled by Catman software.

The specific cutting energy is calculated using Equation (3). To convert the output voltage values to force 
values using the calibration matrix, the routines programmed in the Microsoft Excel program (Korman, 2014) have been used. In addition, the same routine is used to calculate the average and maximum value of force and the energy (work) used for cutting a rock sample. The cutting energy is obtained by numerical integration of the tangential component of the cutting force on the length of the cut, or on the path (Korman at al., 2015b), and calculated using the Equation (10).

$$
E_{R}=\int_{0}^{s} F_{C} \cdot d s
$$

where:

$E_{R}$ - energy (work) for rock cutting (J),

$F_{C}$ - tangential component of cutting force $(\mathrm{N})$,

$s \quad$ - length of the cut (m).

\subsection{Assessment of the volume of the rock chips produced during cutting and drilling}

Prior to measuring, the rock samples were dried in a dryer to a constant mass and weighed on the Mettler Toledo XS6002S balance. By means of the vernier caliper the dimensions of the rock sample (length, width and height) were measured. The multiplication of length, width and height provided the calculated volume of the rock sample. Volumetric density is calculated using the Equation (11).

$$
\rho=\frac{m_{s}}{V}
$$

where:

$$
\begin{aligned}
& \rho-\text { volumetric density }\left(\mathrm{kg} / \mathrm{m}^{3}\right), \\
& m_{s}-\text { mass of sample in dry state }(\mathrm{kg}), \\
& V-\text { volume of sample }\left(\mathrm{m}^{3}\right) .
\end{aligned}
$$

The volume of rock chips produced during drilling is calculated in two ways: by the difference in mass of the rock sample before and after drilling and by the geometrical size of the boreholes. After drilling, the rock sample was cleansed from the rock chips and dried in the drier to a constant mass and weighed. The difference in mass of the sample before and after drilling is the mass of rock chips. From the ratio of mass and volumetric density, it is possible to calculate the volume of rock chips (12).

$$
V_{r}=\frac{m_{s}-m_{s 1}}{\rho}=\frac{m_{r}}{\rho}
$$

where:

$\rho \quad-$ volumetric density $\left(\mathrm{kg} / \mathrm{m}^{3}\right)$,

$m_{s}$ - mass of sample in dry state before drilling $(\mathrm{kg})$,

$m_{s 1}$ - mass of sample in dry state after drilling $(\mathrm{kg})$,

$m_{r}-$ mass of rock chips $(\mathrm{kg})$,

$V_{r}$ - volume of rock chips $\left(\mathrm{m}^{3}\right)$.

Similarly, the geometric sizes (outer and inner diameter and height) of the borehole were measured and the volume of rock chips was calculated using the equation for calculating the volume of the hollow cylinder (13).

$$
V_{r}=\frac{D_{v}^{2}-D_{u}^{2}}{4} \cdot \pi \cdot h
$$

where:

$D_{v}$ - outer diameter of borehole (m),

$D_{u}$ - inner diameter of borehole $(\mathrm{m})$,

$h$ - depth of borehole (m).

Determining the volume of rock chips produced during cutting is very similar to the previously described process. The sample is dried to a constant mass and, in a dry state, the sample size is measured and the volumetric density is calculated. After measuring the cutting energy, the rock sample is thoroughly cleansed from the fragments formed by cutting and weighed. No drying of the sample was necessary since the linear cutting machine does not use a cooling medium, nor was the removal of rock chips necessary. Since the mass of rock chips produced in one cut is very small, and since it is recommended that the mass of rock chips should be at least ten times the scale resolution $(1 \mathrm{~g})$, cutting along the whole width of the sample was performed. In order to determine the mass of the rock chips generated during one cut, it was necessary to determine the number of cuts. The number of cuts is determined by counting the passes of the cutting tool on the surface of the sample. The mass of rock chips produced during one cut can be obtained from the ratio of the total weight of the rock chips generated by cutting and the number of cuts. The volume of the rock chips generated during one cut is calculated using the Equation (14).

$$
V_{r}=\frac{m_{s}-\frac{m_{s 1}}{n_{r}}}{\rho}=\frac{m_{r}}{\rho}
$$

where:

$$
\begin{aligned}
& \rho-\text { volumetric density }(\mathrm{kg} / \mathrm{m} 3), \\
& m_{s}-\text { mass of sample in dry state before cutting }(\mathrm{kg}), \\
& m_{s l}-\text { mass of sample in dry state after cutting }(\mathrm{kg}), \\
& n_{r}-\text { number of cuts } \\
& m_{r}-\text { mass of rock chips formed during one cut }(\mathrm{kg}), \\
& V_{r}-\text { volume of rock chips formed during one cut }\left(\mathrm{m}^{3}\right) .
\end{aligned}
$$

\section{Analysis of results of measurement and discussion}

The measurement of the values needed to calculate the specific drilling energy using the measurement system for measuring energy was performed during the drilling of two boreholes. The LabVIEW program uses the stored measurement data (Microsoft Office Excel files) and graphic interfaces (diagrams: total active power - time and energy - time) of the LabVIEW software to determine the start and end time of the idling of the laboratory drilling rig, the average value of idle power, and 


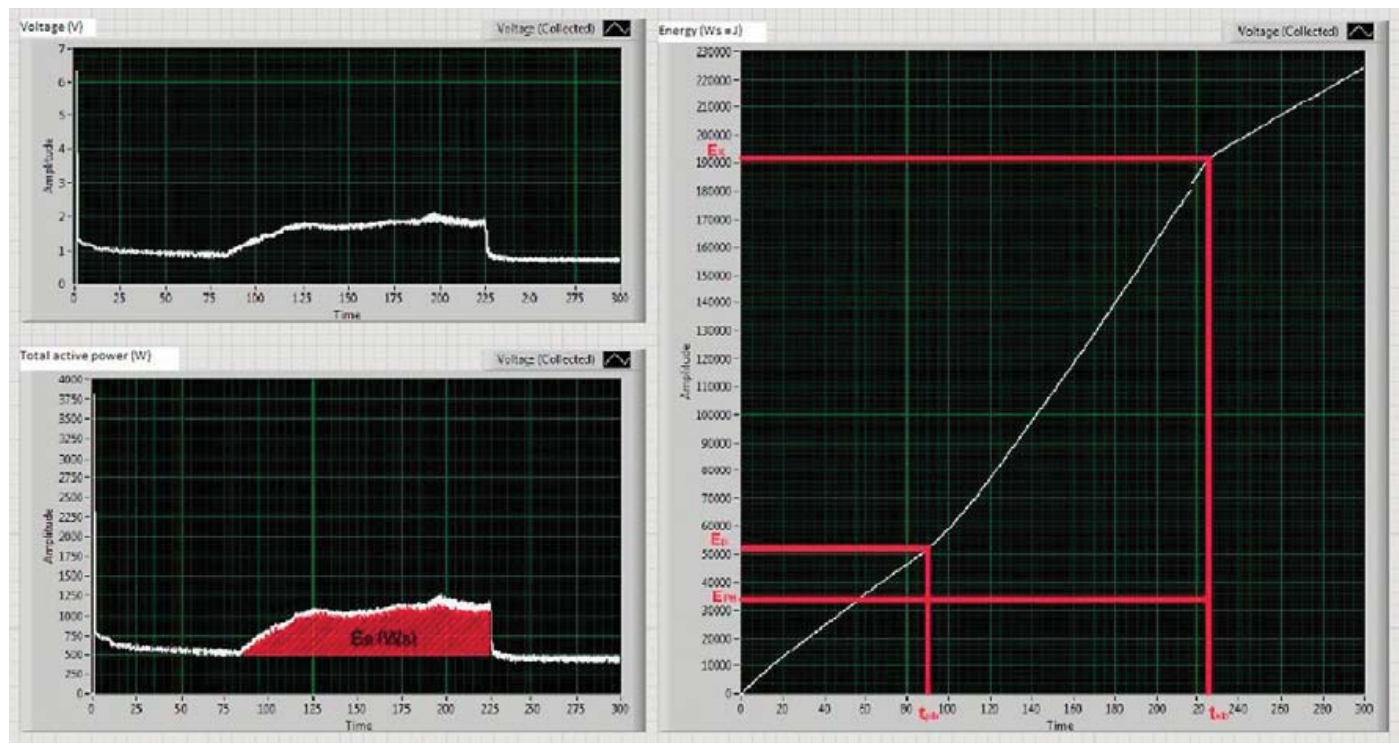

Figure 5: LabVIEW graphical interface during drilling of the first borehole

Table 3: Measurements of the values needed to calculate the specific drilling energy

\begin{tabular}{|c|c|c|c|c|c|c|}
\hline \multirow{4}{*}{$\begin{array}{l}\text { No. of } \\
\text { bore-holes }\end{array}$} & \multicolumn{4}{|c|}{ Energy } & \multirow{2}{*}{$\begin{array}{l}\text { Volume of } \\
\text { rock chips }\end{array}$} & \multirow{2}{*}{$\begin{array}{c}\text { Specific } \\
\text { drilling } \\
\text { energy }\end{array}$} \\
\hline & $\begin{array}{c}\text { at start } \\
\text { of drilling }\end{array}$ & $\begin{array}{l}\text { at end of } \\
\text { drilling }\end{array}$ & idle & for drilling & & \\
\hline & $E_{\mathrm{p}}$ & $E_{\mathrm{K}}$ & $E_{\mathrm{PH}}$ & $E_{\mathrm{B}}$ & $V_{r}$ & $S E_{\mathrm{B}}$ \\
\hline & $(\mathrm{J})$ & $(\mathrm{J})$ & $(\mathrm{J})$ & $(\mathrm{J})$ & $\left(\mathrm{m}^{3}\right)$ & $\left(\mathrm{MJ} / \mathrm{m}^{3}\right)$ \\
\hline \multirow{2}{*}{1} & \multirow{2}{*}{51948} & \multirow{2}{*}{190718} & \multirow{2}{*}{34532} & \multirow{2}{*}{104237} & $3.26550 \cdot 10^{-5}$ & 3192.06 \\
\hline & & & & & $3.30202 \cdot 10^{-5}$ & 3156.77 \\
\hline \multirow{2}{*}{2} & \multirow{2}{*}{41711} & \multirow{2}{*}{183854} & \multirow{2}{*}{26266} & \multirow{2}{*}{115877} & $3.26550 \cdot 10^{-5}$ & 3548.52 \\
\hline & & & & & $3.41001 \cdot 10^{-5}$ & 3398.14 \\
\hline
\end{tabular}

Table 4: Measurements of the values needed to calculate the volume of rock chips using mass difference before and after drilling

\begin{tabular}{|c|c|c|c|c|}
\hline $\begin{array}{l}\text { Sample } \\
\text { weight in } \\
\text { dry state } \\
\text { before } \\
\text { drilling }\end{array}$ & $\begin{array}{c}\text { Sample } \\
\text { weight in } \\
\text { dry state } \\
\text { after } \\
\text { drilling }\end{array}$ & $\begin{array}{c}\text { Mass } \\
\text { of rock } \\
\text { chips per } \\
\text { borehole }\end{array}$ & $\begin{array}{c}\text { Volumetric } \\
\text { density }\end{array}$ & $\begin{array}{c}\text { Volume } \\
\text { of rock } \\
\text { chips }\end{array}$ \\
\hline$m_{\mathrm{s}}$ & $m_{\mathrm{s} 1}$ & $m_{r} / 2$ & $\rho$ & $V_{\mathrm{r}}$ \\
\hline$(\mathrm{kg})$ & $(\mathrm{kg})$ & $(\mathrm{kg})$ & $\left(\mathrm{kg} / \mathrm{m}^{3}\right)$ & $\left(\mathrm{m}^{3}\right)$ \\
\hline \multirow{2}{*}{3.2663} & \multirow{2}{*}{3.0978} & 0.08425 & \multirow{2}{*}{2580} & $\begin{array}{c}3.265 \\
50 \cdot 10^{-5}\end{array}$ \\
\hline & & 0.08425 & & $\begin{array}{c}3.265 \\
50 \cdot 10^{-5}\end{array}$ \\
\hline
\end{tabular}

time and energy of start and the end of drilling (see Figure 5), in order to calculate the values needed to calculate the energy used for drilling, i.e. the specific drilling energy (section 2.2). The results of measurement and calculation are shown in Table 3 .

Determination of the volume of rock chips is explained in Chapter 2.4 of this paper, while the measurement results are shown in Tables $\mathbf{4}$ and $\mathbf{5}$.
Table 5: Results of measurement of the values needed to calculate the volume of rock chips by the geometrical size of the borehole

\begin{tabular}{|l|c|c|c|c|}
\hline \multirow{2}{*}{$\begin{array}{l}\text { No. of } \\
\text { borehole }\end{array}$} & $\begin{array}{c}\text { Borehole } \\
\text { depth }\end{array}$ & $\begin{array}{c}\text { Outer } \\
\text { borehole } \\
\text { diameter }\end{array}$ & $\begin{array}{c}\text { Inner } \\
\text { borehole } \\
\text { diameter }\end{array}$ & $\begin{array}{c}\text { Volume } \\
\text { of rock } \\
\text { chips }\end{array}$ \\
\cline { 2 - 5 } & $\boldsymbol{h}$ & $\boldsymbol{D}_{\mathbf{v}}$ & $\boldsymbol{D}_{\mathbf{u}}$ & $\boldsymbol{V}_{\mathbf{r}}$ \\
\cline { 2 - 5 } & $(\mathrm{m})$ & $(\mathrm{m})$ & $(\mathrm{m})$ & $\left(\mathrm{m}^{3}\right)$ \\
\hline \multirow{2}{*}{2} & 0.0538 & 0.06888 & 0.06295 & $\begin{array}{c}3.302 \\
02 \cdot 10^{-5}\end{array}$ \\
\hline & 0.0552 & 0.06892 & 0.06295 & $\begin{array}{c}3.410 \\
01 \cdot 10^{-5}\end{array}$ \\
\hline
\end{tabular}

Due to the fact that two boreholes on a rock sample were drilled and assuming that the geometrical characteristics (drilling depth and drill bit diameter) of the drilled boreholes are the same, the mass of the rock chips obtained by drilling is divided by the number of boreholes.

The results in Tables $\mathbf{4}$ and $\mathbf{5}$ show that the volumes of rock chips are very similar and therefore the specific drilling energy is slightly different (see Table 3). The same measuring system was used to measure cutting en- 


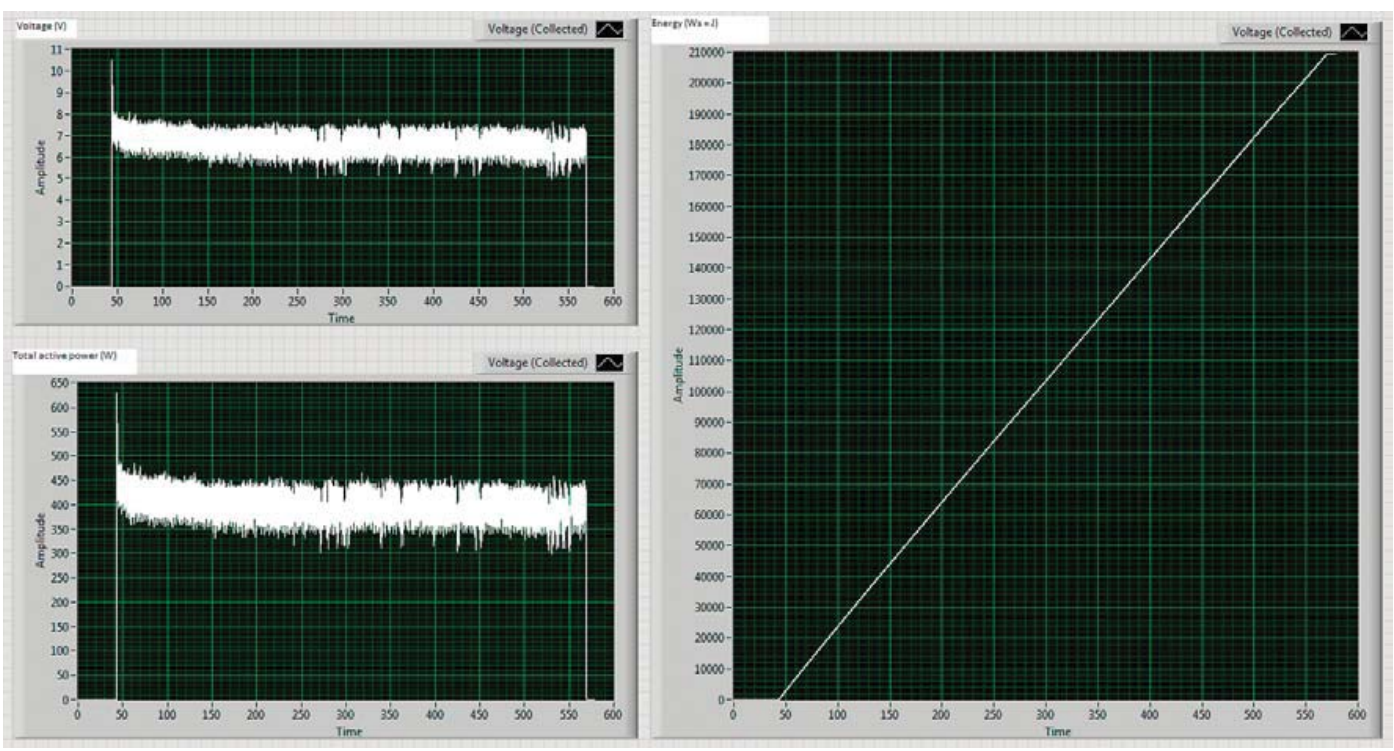

Figure 6: LabVIEW graphic interface during cutting a rock sample on the linear cutting machine

Table 6: Results of measurement of values required to calculate the specific cutting energy

\begin{tabular}{|c|c|c|c|c|c|c|}
\hline \multirow{4}{*}{ No. } & \multicolumn{3}{|c|}{ Components of cutting force } & \multirow{2}{*}{ Cutting energy } & \multirow{2}{*}{$\begin{array}{c}\text { Mean value of the } \\
\text { volume of rock chips }\end{array}$} & \multirow{2}{*}{$\begin{array}{c}\text { Specific cutting } \\
\text { energy }\end{array}$} \\
\hline & Tangential & Sideway & Normal & & & \\
\hline & $F_{\mathrm{c}}$ & $F_{\mathrm{f}}$ & $F_{\mathrm{n}}$ & $E_{\mathrm{R}}$ & $V_{\mathrm{r}}$ & $S E_{\mathrm{R}}$ \\
\hline & $(\mathrm{N})$ & $(\mathrm{N})$ & $(\mathrm{N})$ & $(\mathrm{J})$ & $\left(\mathrm{m}^{3}\right)$ & $\left(\mathrm{MJ} / \mathrm{m}^{3}\right)$ \\
\hline 1 & 9.00 & 2.05 & 17.50 & 2.83 & \multirow{10}{*}{$6.04958 \cdot 10^{-9}$} & 468.59 \\
\hline 2 & 9.66 & 0.71 & 15.50 & 2.89 & & 478.22 \\
\hline 3 & 6.96 & 2.72 & 17.38 & 2.53 & & 417.70 \\
\hline 4 & 4.57 & 2.38 & 10.67 & 1.86 & & 308.11 \\
\hline 5 & 3.42 & 2.14 & 8.29 & 1.64 & & 270.62 \\
\hline 6 & 5.44 & 2.45 & 12.51 & 2.28 & & 376.71 \\
\hline 7 & 6.47 & 1.42 & 10.58 & 2.07 & & 342.74 \\
\hline 8 & 7.30 & 1.58 & 12.91 & 2.15 & & 354.90 \\
\hline 9 & 6.88 & 2.03 & 14.91 & 2.71 & & 447.44 \\
\hline 10 & 8.87 & 1.89 & 18.59 & 3.01 & & 498.28 \\
\hline \multicolumn{6}{|c|}{ Mean value of the specific cutting energy } & 396.33 \\
\hline
\end{tabular}

Table 7: Results of measurement of values required to calculate the volume of rock chips

\begin{tabular}{|c|c|c|c|c|c|c|c|}
\hline \multirow[t]{3}{*}{ No. } & $\begin{array}{c}\text { Sample weight } \\
\text { in dry state } \\
\text { before cutting }\end{array}$ & $\begin{array}{c}\text { Sample weight } \\
\text { in dry state after } \\
\text { cutting }\end{array}$ & $\begin{array}{c}\text { Total mass } \\
\text { of rock } \\
\text { chips }\end{array}$ & $\begin{array}{l}\text { Number } \\
\text { of cuts }\end{array}$ & $\begin{array}{c}\text { The mass of rock } \\
\text { chips created } \\
\text { during one cut }\end{array}$ & $\begin{array}{c}\text { Volumetric } \\
\text { density }\end{array}$ & $\begin{array}{c}\text { Volume } \\
\text { of rock chips }\end{array}$ \\
\hline & $m_{s}$ & $m_{\mathrm{s} 1}$ & $m_{\text {ruk }}$ & $n_{r}$ & $m_{\mathrm{r}}$ & $\rho$ & $\boldsymbol{V}$ \\
\hline & $(\mathrm{kg})$ & $(\mathrm{kg})$ & $(\mathrm{kg})$ & & $(\mathrm{kg})$ & $\left(\mathrm{kg} / \mathrm{m}^{3}\right)$ & $\left(\mathrm{m}^{3}\right)$ \\
\hline 1 & 0.98101 & 0.97710 & 0.00391 & 234 & $1.67094 \cdot 10^{-5}$ & \multirow{2}{*}{2580} & $6.47651 \cdot 10^{-9}$ \\
\hline 2 & 0.97710 & 0.97372 & 0.00338 & 233 & $1.45064 \cdot 10^{-5}$ & & $5.62265 \cdot 10^{-9}$ \\
\hline \multicolumn{7}{|c|}{ The mean value of the volume of rock chips } & $6.04958 \cdot 10^{-9}$ \\
\hline
\end{tabular}

ergy, but the results obtained are practically of no use due to the fact that it is very difficult to distinguish idle energy from cutting energy (see Figure 6). The possible reason for this is the small cutting depth $(100 \mu \mathrm{m})$ and the high weight of the coulisse mechanism of the linear cutting machine used for converting the rotating movement of the electric motor in the linear movement of the console on which the tool holder is located.

Comparison of the energy-time diagrams during cutting, i.e., drilling shows that the drilling energy - time 
diagram (see Figure 5) changes the inclination of the drilling direction relative to the slope of the idle direction. In other words, the slope of the drilling direction is increased, i.e. the slope is steep because the drilling rig uses up more energy in time, and after the end of drilling, the slope has a lower angle characteristic of idling. This trend has not been observed on the cutting energy - time diagram, i.e. the direction has a very similar slope during cutting and idling of electric motors (see Figure 6).

Simultaneously, the components of cutting force were measured by the measuring system with a three-axis force transducer. Using the procedures and Equations (3), (10), (11) and (14), the cutting energy, i.e. the specific cutting energy were calculated. The results of the measured values needed to calculate the specific cutting energy are shown in Table 6. The cutting depth of the cutting element is, by means of the cutting depth adjustment mechanism, set to the cutting depth of a single diamond grain impregnated in the coring bit segment, or $100 \mu \mathrm{m}$ (Chiaia et al. 2013).

Determination of the volume of rock chips is explained in Chapter 2.4. of this article, and the measurement results are presented in Table 7.

\section{Conclusion and guidelines for further work}

The results presented in Tables 3 and $\mathbf{6}$ shows that the specific drilling energy is much higher than the specific cutting energy, although the cutting depth is adapted to the size of one diamond grain impregnated in the coring bit segment. A probable reason for this is the higher number of diamond grains which are in contact with the rock sample when it is drilled while in the rock cutting process there is only one cutting element. In addition, the cutting energy depends on the cutting tool geometry and cutting conditions. When cutting in unrelieved conditions, the cutting energy is considerably higher than the cutting energy in relieved conditions where there are two or more free surfaces for the formation of cracks (Copur, 2009). The orientation and the rake angle of the tool also affect the cutting energy. Schei et al. (2000) concluded that the increase of the negative rake angle results in the increased specific cutting energy. The cutting area and cutting shape also significantly affect the cutting energy, and increasing the ratio of width and depth of the cut increases the specific cutting energy (Korman et al., 2016). Accordingly, it can be concluded that it is necessary to establish the number and dimensions of diamond grains on the drill bit that are in contact with the rock when drilling. Dividing the specific drilling energy with the number of diamond grains would provide the data on the specific drilling energy of a single diamond grain and the average size of the diamond grain would confirm the assumed depth of cutting stated in literature (Chiaia et al., 2013) when testing the specific cutting energy.
The energy measurement by means of the energy measurement system used for cutting or drilling is a much simpler method of measurement compared to the measurement system with a force transducer. Unfortunately, as stated above, the data obtained when measuring the cutting energy using a measuring system for energy measurement is of no use for calculating the specific cutting energy. The main reason is that the increase of energy during cutting is negligible compared to idle energy. The linear cutting machine is designed in such a way that the crank mechanism ensures a similar energy consumption from the power grid, regardless of whether the machine is cutting or not, which in this case limits the measurement.

From the analysis of the investigations carried out, there are guidelines for the continuation of the research dependency of the specific energy of rock cutting on the specific drilling energy:

1. Instead of the laboratory coring bit for the production of samples, it is necessary to place the drill bit, using the adapter, with diamond segments used in drilling the exploration boreholes to confirm the reserves of the dimension stone in the deposit.

2. Using a microscope, determine the number and dimensions of diamond grains on the drill bit which is in contact with the rock sample that is being drilled. This data could provide the answer to the question why the specific drilling energy is significantly greater than the specific cutting energy.

3. The specific cutting energy measurement should be repeated using the measuring system for cutting energy measurement with a data acquisition device that allows a higher sampling rate or better resolution (HBM Spider 8). This would lead to the conclusion that it is possible to record the difference between the cutting energy and the idle energy of the electric motor for linear cutting machine. If possible, the measured cutting energy would be compared to the cutting energy obtained by the measuring system with a three-axis force transducer. The test procedure would be carried out on the same rock samples and by the methods and calculations described in this paper.

4. It is essential to create a system for measuring operating parameters of a laboratory drilling rig - its normal component of drilling force (thrust) and torsion (torque), rotation speed, vertical displacement of drill bit, and water flow to extract the accumulated rock chips from the borehole - needed to calculate the specific drilling energy. It would consist of force and torque transducer, rotation speed measuring sensor, linear variable differential transformer (LVDT sensor), water flowmeter, data acquisition device and computer. Drilling energy measurement is required by means of the measuring system for measuring the operating parameters of the drilling rig, as well as by means of 
the measuring system for measuring the electric active power of the three-phase electric motor drive and compare the measured results to confirm that the measuring system for measuring active power provides the relevant data on the specific drilling energy.

5. The measurement of cutting and drilling energy using both measuring systems should be carried out on samples of different types of rock (by collecting, if possible, samples of magmatic, sedimentary and metamorphic rocks). After measurement, the statistical data will be processed in order to determine the existence and nature of the dependence of specific energy of rock cutting on the specific drilling energy.

6. A partial estimation of measurement uncertainty of measuring systems was performed. When completed, it will be used as an indicator of the quality of the measurement results. In addition, by analysing certain contributions of measurement uncertainty, the weak points of the measuring system will be identified, thus opening up opportunities for further improvements in the measurement systems.

After the laboratory tests, measurements of the specific cutting and drilling energy will be performed on the exploitation field of dimension stone from which the samples for laboratory testing were provided. The drill energy would be measured on the drilling rig which is used for drilling the exploration wells, while the cutting energy would be measured on the chain saw by the method described in another paper (Korman, 2014). The specific cutting and drilling energy values obtained by laboratory and field tests will be compared to demonstrate how well the testing in laboratory conditions can simulate the conditions in a real environment.

\section{References}

Chiaia, B., Bori-Brunetto, M., Carpinteri, A (2013): Mathematical modelling of the mechanics of core drilling in geomaterials. Machining Science and Technology, 17, 1-25.

Copur, H. (2009): Linear stone cutting tests with chisel tools for identification of cutting principles and predicting per- formance of chain saw machines. Int. J. Rock Mech. \& Min. Sci., 45, str. 104-120.

Korman, T. (2014): Influence of constructional and operational parameters on chain saw performance. Doctoral Thesis, University of Zagrebu, Faculty of Mining, Geology and Petroleum Engineering.

Korman, T., Bedeković, G., Kujundžić, T., Kuhinek, D. (2015a): Impact of physical and mechanical properties of rocks on energy consumption of jaw crusher. Physicochemical Problems of Mineral Processing, 51 (2), 461 - 475.

Korman, T., Kujundžić, T., Kuhinek, D. (2015b): Simulation of the chain saw cutting process with a linear cutting machine. International Journal of Rock Mechanics and Mining Sciences, 78, 283-289.

Korman, T., Kujundžić, T., Lukačić, H., \& Martinić, M. (2016): The Impact of Area and Shape of Tool Cut on Chain Saw Performance. The Mining-Geology-Petroleum Engineering Bulletin, 31(3), 1-13.

Mellor, M. (1976a): Mechanics of cutting and boring. Part II: Kinematic of axial rotation machines. Cold Regions Research and Engineering Laboratory, Hanover, New Hampshire, USA, Report 76-16.

Mellor, M. (1976b): Mechanics of cutting and boring. Part III: Kinematic of continuous belt machines. Cold Regions Research and Engineering Laboratory, Hanover, New Hampshire, USA, Report 76-17.

Mellor, M. (1978): Mechanics of cutting and boring. Part VIII: Dynamics and energetics of continuous belt machines. Cold Regions Research and Engineering Laboratory, Hanover, New Hampshire, USA, Report 78-11.

Mellor, M. (1981): Mechanics of cutting and boring. Part VII: Dynamics and energetics of axial rotation machines. Cold Regions Research and Engineering Laboratory, Hanover, New Hampshire, USA, Report 81-26.

Schei, G., Fjaer, E., Detournay, E., Kenter, CJ., Fuh, GF., Zausain, F. (2000): The Scratch Test: An Attractive Technique for Determining Strength and Elastic Properties of Sedimentary Rocks. Annual Technical Conference and Exhibition (2000) SPE 63255, Society of Petroleum Engineers, str 1-7.

Teale, R. (1965): The Concept of Specific Energy in Rock Drilling. International Journal of Rock Mechanics and Mining Science, 2, 57-73.

Wojtanowicz, A.K., Kuru, E. (1993): Mathematical modeling of PDC bit drilling process based on a single cutter mechanics. Journal of Energy Resources Technology, 115 (4), 247-256.

The Mining-Geology-Petroleum Engineering Bulletin and the authors $\odot$, 2018, pp. 23-32, DOI: 10.17794/rgn.2018.3.3 


\section{SAŽETAK}

\section{Zavisnost specifične energije rezanja stijena od specifične energije bušenja}

Specifična energija veličina je koja povezuje radne veličine stroja sa značajkama stijene u kojoj stroj radi, a jednaka je ukupnome radu potrebnom za razrušavanje jediničnoga volumena stijene. Pretpostavlja se da kod strojeva koji imaju istu ili sličnu mehaniku razrušavanja stijena, a koji se koriste za različite namjene (npr. rezanje i bušenje stijena), postoji znatna zavisnost između specifičnih energija. Prilikom eksploatacije arhitektonsko-građevnoga kamena često se koristi lančana sjekačica i rotacijska bušilica, tj. strojevi koji služe za rezanje, odnosno bušenje stijene, a čija je mehanika razrušavanja vrlo slična. Radi određivanja zavisnosti specifične energije rezanja stijena o specifičnoj energiji bušenja provedena su preliminarna laboratorijska ispitivanja na uređaju za pravolinijsko rezanje stijena i laboratorijskoj bušilici kojima je simulirano rezanje stijena lančanom sjekačicom, tj. bušenje stijena rotacijskim bušenjem. Analizom mjernih rezultata dobivene su smjernice za nastavak laboratorijskih ispitivanja odnosno provedbu terenskih ispitivanja.

\section{Ključne riječi:}

razrušavanje stijena, bušenje, rezanje, specifična energija

\section{Authors contribution:}

This paper is a part of PhD research of the author Davor Antoljak (graduate engineer of mining) who led the research and analysed measurement results. The supervisors of PDh thesis, Trpimir Kujundžić (Full Professor) initialized the idea and analysed measurement results while Dalibor Kuhinek (Assistant Professor) built measurement transducer used during cutting and drilling. Also, he made Labview virtual instrument and data analysis of energy measurement during boring. Tomislav Korman (Assistant Professor) built measurement transducer used during cutting and made data analysis of energy during cutting. 